\title{
BOARD DYNAMICS AND FIRM VALUE: THE ROLE OF AUDIT QUALITY INLISTED OIL AND GAS FIRMS IN NIGERIA
}

\author{
USMAN Tanimu Gadi ${ }^{1}$, BELLO Mohammed Bamanga ${ }^{2}$, EGBERI Oyinemi Elvis ${ }^{3}$ and \\ ABOLUGBE, K. E ${ }^{4}$. \\ ${ }^{1}$ Department of Accounting Nasarawa State University, Keffi \\ 2 Department of Accounting, Federal University of Lafia \\ ${ }^{3}$ Nasarawa State; Nigeria College of Accountancy, Kwall, Jos, Plateau State \\ ${ }^{4}$ Department of Accounting Nasarawa State University, Keffi
}

DOI: 10.46609/IJSSER.2021.v06i02.013 URL: https://doi.org/10.46609/IJSSER.2021.v06i02.013

\begin{abstract}
The study is based on positivism research philosophy and it assesses the moderating effect of audit quality on the relationship between board dynamics and firm value in listed oil and gas firms in Nigeria from 2010 to 2019. The study adopts descriptive research design with ordinary least square technique for the analysis. It was found that moderated board magnitude has negative and significant effect on firm value which signal reduction in the wealth of the shareholders while moderated board diversity has positive and significant effect on firm value however, moderated board proficiency has no significant effect on firm value. Based on the finding, it therefore means that audit quality gives credence to the financial reports of an organization therefore, oil and gas companies should engage the services of reputable audit firms that can monitor the activities of the board in order to improve their firm value. Also, women directors due to their different experiences are expected to have different perspectives than men in some fields and some segments of the market. Therefore, those firms without female representation should endeavor to bring in female director(s) so as to enjoy such benefit in their organization.
\end{abstract}

Keywords: Board Dynamics, Firm Value, Audit Quality

\section{INTRODUCTION}

Creation of value to the stakeholders' investment is the main goal of every company (Panahi, Preece, Zakaria \& Rogers, 2014). The shareholders are directly concerned by value added as it improved the investments made by shareholders and achieve the projected profit. 


\section{International Journal of Social Science and Economic Research}

ISSN: $2455-8834$

Volume:06, Issue:02 "February 2021"

Globalization in real and financial markets has amplified the burden on managers to deliver superior performance, and value for their shareholders. Managers' ultimate responsibility often is to present an increasing shareholder value. Even though managers exist to create value for their owners, corporate managers do not constantly take action to maximize shareholder value, because of apparent conflicts with other objectives which includes manager's interest (Panahi, Preece, Zakaria \& Rogers, 2014).

Changes in the firm value on annual basis is paramount to any business most especially stakeholders of an organization. However, firm value is affected by external and internal mechanism. Board dynamics play a significant role in enhancing firm's value. When there is a separation of ownership between the owners and the managers, the shareholders are unable to engage in management and it is the duty of the managers to represent the shareholder's interests. The board of directors of companies owns the task to ensure that managers of corporations use the assets to maximize shareholders' value. Based on this, the board of directors is also anticipated to facilitate and monitor the effectiveness of management to ensure legal compliance and to prevent unlawful and immoral conduct. Corporate governance is saddled with responsibility to derive competitive advantage in a free market knowledge economy (Makki \& Lodhi, 2013). This competitive edge is possible if corporate governance measures enhances value through exploiting all available resources. A good corporate governance practices ensure better decision making, operational efficiency, and reduction in wastes. It further balances the interests of all stakeholders, including executives and non- executive (Shleifer \& Vishny, 1997). Shareholders can believe that companies with good corporate governance practices make sure that free cash flow should be returned to shareholders as dividend rather than being expropriated by the insiders (Porte, Florencio \& Shleifer, 2002).

The board magnitude plays a significant role because they have an important position on boards, representing the interests of large shareholders and institutional investors (Kirchmaier \& Grant, 2005). Therefore, their presence influences the firm value by aligning managers interest to the shareholders' wealth maximization. In the same way, board gender diversity will have a positive effect on firm value when its presence on boards increases from low to moderate levels. But, as the proportion of female directors increases from moderate to higher levels, they will impact negatively on corporate value, since gender diversity is a demographic attribute that individuals use in order to categorise themselves (Knouse \& Dansby, 1999).

Based on Securities and Exchange Commission (SEC) submission that director with prior accounting-related experience in financial reporting should have experience as a public accountant, auditor, principal financial or accounting officer, or controller. With this experience, those board with financial proficiency should be able to conduct their duties that can improve firm value. However, the positive theory of agency argues that managers may behave 


\section{International Journal of Social Science and Economic Research}

ISSN: $2455-8834$

Volume:06, Issue:02 "February 2021"

opportunistically to maximize their own welfare (Strong \& Waterson, 1987). This agency problem can be mitigated through the protections derived from good corporate governance structures (Okeahalam \& Akinboade, 2003) such as engagement of good audit companies to monitor management activities.

The primary aim of the external auditor is to ensure that the financial statements forwarded bythe board of directors to the shareholders are reliable (Mautz \& Sharaf, 1961). Coupled with this is the effort made by the external auditor in minimizing information asymmetry between management and shareholders (Fama, 1980). In addition, the external audit is deemed to be a controlling factor used by the firm to address agency issues and any manipulated changes in the accounting information (Jensen \& Meckling, 1976; Watts \& Zimmerman, 1983). Also, external audit helps in lessening the ownership gap and the control over the firm (Fama \& Jensen, 1983).

Despite the significance of audit quality in moderating the management activities in minimizing information asymmetry and improving management performance which canincrease company's firm value, little has been recognize in literatures to this effect. Most of the literatures such as Dincer and Dincer (2013); Kamangue and Ngugi (2013); Kumar (2015); Suparno and Pitoyo (2016); Villanueva-Villar, Rivo-López and Lago-Penas (2016); Pucheta-

$\neg$ Martínez, Belᄀ-Oms and Olcina $\neg$ Sempere (2016); Gurusamy (2017); Sasidharan and Varghese (2019) mainly ascertained effect of board dynamics on firm value except Baldavoo and Nomlala (2019) that used Ghanaian banks from 2010 to 2017. In light of this, the study ascertained whether audit quality had moderate how board dynamics affected firm value of listed Nigeria oil and gas firms.

In the coming sections of the study, an in-depth explanation of the procedures employed in the study is provided.

\section{LITERATURE REVIEW}

\section{Audit Quality}

According to De Angelo (1981), audit quality as the market assessment of the likelihood that the auditor (i) detect significant distortions of the financial statements or employers accountingsystem and (ii) report significant distortions. The Quality of an audit is the probability in whichan auditor finds and reports on the existence of a breach in the accounting system of the concerned auditor's client (DeAngelo, 1981). According to Watts and Zimmerman (1986), audit quality is the qualities that the auditor possesses to discharge his duties well which includes expertise, integrity and independence. Also, according to Adeyemi and Akuniyi (2010), auditors whose attributes are associated with professionalism, conservativeness, large size, experience with 


\section{International Journal of Social Science and Economic Research}

ISSN: $2455-8834$

Volume:06, Issue:02 "February 2021"

clients, possession of wide range of skills, independence and industry expertise are those whose audit quality is high. From this assertation, it is expected that audit quality should mitigate the board daily operations. It is on this that the study ascertained the role of audit quality on the relationship between board dynamics and firm value.

The external auditing ensures that the financial statements presented by management are truthfully stated and are presented in accordance with the necessary reporting and legal frameworks. The independent verification and opinion provided by auditors provides credibility of the financial statements (Cahan \& Sun, 2015). In addition, as per the auditing standards, external auditors are required to communicate and discuss the quality of the audit with the audit committee of an entity. This emphasise the significance of an audit quality. As explained by Zhang (2017), the quality of an audit is anticipated to restrain and constrain opportunistic behaviour of management, in addition to the reduction of the risk that the financial statements contain omissions and material misstatements. Usually, audit quality would mean the extent to which auditors adhered to the auditing standards and professionalism in the discharge of their duties. This suggests that the auditors must execute their duties with due regard to professional care, competence, and independence. However, these attributes of audit quality are not easily measured. As a result, researchers have used other variables as proxies for audit quality. Board Dynamics

Board dynamics refers to the way individual board directors interact with each other in the carrying out of their duty as director with the objective of collectively generating economic value for the organization. Some of the board dynamics used in this study are thus discussed:

\section{Board Magnitude}

This refers to the total number of directors on the board at accounting year end. When the number of directors on the board is large, firms would get more access to various resources in comparison to the case when board magnitude is small. The larger board of directors, the more experienced and knowledgeable people will be available which will lead to more careful learning, decision making process and ultimately better firm performance. Larger board of directors is harmful to firms' performance (Switzer \& Tang, 2009). According to the resource dependence theory, the more the members to the board, the better would be the quality of decisions taken by the firm. This would then enhance firm performance. On the contrary, a lesser number of members on the board would increase the chances of managers overdoing onpersonal pursuits and utilizing firms' resources for meeting personal needs (Jensen,1993).

Ho1: Audit quality has no significant effect on the relationship between board magnitudeand firm value of listed oil and gas firms in Nigeria 


\section{International Journal of Social Science and Economic Research}

ISSN: $2455-8834$

Volume:06, Issue:02 "February 2021"

\section{Board Diversity}

Gender representation on corporate boards of directors refers to the proportion of women and men who occupy board member positions. The diversity of the board of directors could have a positive effect on firm performance as more diversified boards are taking their decisions based on a wider range of alternatives than more homogeneous boards. Moreover, women directors due to their different working and non-working experiences are expected to have different perspectives than men in some fields and some segments of the market. The impact of female directors on outcomes depends on their presence on boards. According to Knouse and Dansby (1999), gender diversity will have a positive effect on firm performance when its presence on boards increases from low to moderate levels. But, as the proportion of female directors increases from moderate to higher levels, they will impact negatively on corporate value, since gender diversity is a demographic attribute that individuals use in order to categorise themselves and others into social groups.

Ho2: Audit quality has no significant effect on the relationship between board diversity and firm value of listed oil and gas firms in Nigeria

\section{Board Proficiency}

Proficiency is thus assessed on the basis of criteria conferring the capacity to carry out the task's incumbent on a board member. According to Blue Ribbon Committee (1999), financial proficiency refers to past employment experience in finance or accounting, requisite professional certification in accounting, or any other comparable experience or background which results in the individual's financial sophistication, including being or having been a CEO or other senior officer with financial oversight responsibilities. Securities and Exchange Commission (SEC) focused on whether the director has prior accounting-related experience with SEC financial reporting and suggested that such directors will have experience as a public accountant, auditor, principal financial or accounting officer, or controller (DeFond, Hann \& Hu, 2005).

Ho3: Audit quality has no significant effect on the relationship between board proficiency and firm value of listed oil and gas firms in Nigeria Firm Value

Corporate value is an economic measure which reflects the market value of a business. According to Hasnawati (2005), firm's value is the market value of an organization because firm's value can maximize shareholders wealth, if the stock price increases. According to Güleryüz (2009), firm value was the acquisition and the trade value of the company anticipatedby volunteer buyers and sellers with thorough information about the company free from any problem. Firm value is considered as a crucial thing since it describes the prosperity of the 


\section{International Journal of Social Science and Economic Research}

ISSN: $2455-8834$

Volume:06, Issue:02 "February 2021"

company's owner. Therefore, the manager, as the representative of the company, is responsible to achieve the firm value optimally (Nurul, 2014). A good firm value is able to attract other parties' interests to join the company. Modigliani and Miller (1958) stated that firm value is determined by company's asset earnings power. The positive impact of asset earnings power shows that if the company has higher earning powers, then the asset turnover will be more efficient and the profit will be bigger. As a result, the firm value will also increase.

\section{Board Dynamics and Firm Value}

In a study of Turkish banks, Dincer and Dincer (2013) used regression analysis to examine the relationship between corporate governance and firm value. The study used 2003-2009 data set while panel ordinary least square was used for the analysis. From the analysis, it was found that board size is negatively related to both firm profitability and valuation.

Kamangue and Ngugi (2013) investigate the influence of board attributes on the firm value of firms in Kenya. A multivariate regression model was applied to determine the relativeimportance of each of the four variables with respect to the influence of board attributes on firm value. The study found out that majority of the respondents agreed to a great extent that the size of the board had a material impact on the quality of corporate governance and that monitoring expenses and poor communication in a larger board had been seen as a reason for the support of small board size. Primary data is pruned to noisy and thus meaningless as well as people do not mean what they say, or relatedly, that survey responses are strongly dependent on framing and language thus, secondary data will be more meaningful for this nature of study.

Based on a sample of 61 UAE listed companies, Kumar (2015) examines the determinants of value creation. Size in terms of total assets of a firm is inversely related to value creation. Valueas measured by market to book value of equity is negatively related to the size measured by total assets. Larger the size in terms market capitalization, higher would be the value created. Higher earnings relative to price signify higher value creation. Firms having higher risk are expected to have higher returns. The study finds statistical support for the fact that increasing leverage increases the risk of equity shareholders. Hence leverage increases leads to increased expected returns to account for increased risk for equity shareholders.

Suparno and Pitoyo (2016) analyze how Dividend Policy, Manager Share-Owned, Board Sizeand Profitability, both partially on Value of the Firm of the firm's manufacturing sector. The study uses a quantitative approach, with a sample of 110 companies listed on the Indonesian Stock Exchange (BEI) during the years 2009-2014, with a sample of all manufacturing companies (purposive sampling method). The data was analysis using multiple linear regression. The results showed declared Dividend Policy and Profitability significantly affect the Firm's Value, while 


\section{International Journal of Social Science and Economic Research}

ISSN: $2455-8834$

Volume:06, Issue:02 "February 2021"

variable Manager Share-Owned and Size of Board of Commissioners declared not affect the value of the Firm.

Villanueva-Villar, Rivo-López and Lago-Penas (2016) analyse the effect of corporate governance on value creation of the companies listed on the Spanish Stock Exchange for the period from 2005 to 2012. In particular, four variables are analyzed: Board Size, Board Independence, Board Diligence (measured by the number of meetings), and Duality (chairmanand chief executive officer being the same person). Over the period of the deepest economic crisis (2009---2012) the most significant variables that had a positive effect on value creation were Board Independence and Board Size.

Pucheta-Martínez, Bel-Oms and Olcina-Sempere (2016) examine impact of female boards institutional directors on corporate performance. The study also examines effect of pressure resistant female directors, who represent institutional investors (investment, pension and mutual funds) that only invest in the company, and do not maintain a business relation with the firm. the result shows that female institutional directors on boards enhance corporate performance, but when they reach a certain threshold on boards (11.72\%), firm value decreases. In line with female institutional directors, pressure resistant female directors on boards also increase firm value, but only up to a certain figure $(12.71 \%$ on boards), above which they have a negative impact on firm performance.

Gurusamy (2017) investigates the impact of corporate governance (board characteristics, audit committee and Ownership Structure) on the financial performance of the selected 357 manufacturing firms listed in Bombay Stock Exchange (BSE) during the period 2006-2015. The study found that board size is positively and significantly linked to both the financial performance measures, i.e. Return on assets (ROA) and Return on Equity (ROE) but the negative and insignificant impact in case of Tobin's Q. Audit committee independence is significant and negatively affected by ROE. The same promoters' shareholding is negatively and significantly related to all the financial measures and there is an insignificant negative relationship between institutional shareholding and both financial performance measures (Tobin's Q and ROA). Sasidharan and Varghese (2019) assess the impact of ownership structure and board characteristics on firm value. The study employs panel data methodology with industry and time fixed effects on a sample of 1042 firms listed in NSE of India and 450 firms listed in SSE of China. The study found promoter ownerships to positively impact a firm's value creation process, while institutional investors exert a negative influence. Although CEO duality enhances firm value in China, the results show otherwise for Indian firms. Additionally, while board independence is positively correlated to firm value in India, it has a negative effect on firms in China. Lastly, the study found that larger board size contributes favorably towards better 


\section{International Journal of Social Science and Economic Research}

ISSN: $2455-8834$

Volume:06, Issue:02 "February 2021"

decision making.

Baldavoo and Nomlala (2019) assess the impact of audit quality on firm value and how corporate government moderate this relationship of 36 Ghanaian banks from 2010 to 2017. Arandom effect regression model was used to estimate the relationships. The results revealed that audit quality have a positive impact on the value of a firm. In addition, the existence of effective corporate governance improves the relationship between the audit quality and the value of the firms. Corporate governance therefore facilitates improved moderation of the relationship between audit quality and the value of firms.

\section{Resource Dependency Theory}

This theory is associated with Pfeffer and Salancik (1978) who focused on the benefits a firm derives by virtue of its linkages with external parties. According to Borlea and Achim (2013), this theory offers an explanation to the complex character of network relationships that are typical of corporate governance relationships. Furthermore, Kyereboah-Coleman (2008) indicates that this theory introduces accessibility to resources by firms, as a critical dimension to the debate on corporate governance. Similarly, this view is supported by Masdoor (2011) and Wanyama and Olweny (2013) who point out that the resource dependency theory explains the role of board of directors in ensuring that management access the resources they require torun firms successfully.

Further, Nguyen, Locke and Reddy (2014) arguing from a resource dependency theory perspective emphasize that a firm's board of directors provides an avenue for it to access crucial resources. Yusoff and Alhaji (2012) point out that this theory explains the importance of board as a resource for the firm. Therefore, the role of a firm's board is wider and it goes beyond the traditional control responsibility stipulated by the agency theory (Yusoff \& Alhaji,2012).

\section{METHODOLOGY}

The study is based on the positivism research philosophy to assess the moderating role of audit quality on the relationship between board dynamics and firm value with focus on descriptive research design. The study covers a period of ten years from 2010-2019 with total sample sizeof six firms. The study used panel data with ordinary least square technique for the analysis. The linear model that explained this relationship is:

$$
F V_{i t}=\beta_{0}+\beta_{1} A Q_{i t}+\beta_{2} A Q * B M_{i t}+\beta_{3} A Q * B D_{i t}+\beta_{4} A Q * B P_{i t}+\varepsilon_{i t}
$$

Where:

FV = Firm Value (Tobin's Q = Market value of equity plus book value of preferredstock plus book 


\section{International Journal of Social Science and Economic Research}

ISSN: 2455-8834

Volume:06, Issue:02 "February 2021"

value of total debt divided by the sum of book value of total assets)

$\mathrm{BS}=$ Board Magnitude (Number of directors at the board)

$\mathrm{BD}=$ Board Diversity (Proportion of female directors to total board members ofthe company)

$\mathrm{BP}=$ Board Proficiency (number of board that have financial background)

$A Q=$ Audit Quality (if the company is audited by Big 4 is denoted as 1otherwise 0)

$\beta 1-\beta 4=$ Coefficient of explanatory variables

$\beta o=$ Constant or Intercept

$\mathrm{e}=$ Error Term.

$\mathrm{i}=$ firm

$\mathrm{t}=$ year

\section{RESULT AND DISCUSSION}

Table 1: Descriptive Statistics

\begin{tabular}{|l|c|c|c|c|c|}
\hline & FV & AQ & AQ_BM & AQ_BD & AQ_BP \\
\hline Mean & 0.016804 & 0.750000 & 6.900000 & 0.146984 & 1.550000 \\
\hline Median & 0.014532 & 1.000000 & 8.500000 & 0.000000 & 2.000000 \\
\hline Maximum & 0.057895 & 1.000000 & 13.00000 & 0.555556 & 4.000000 \\
\hline Minimum & 0.000120 & 0.000000 & 0.000000 & 0.000000 & 0.000000 \\
\hline Jarque-Bera & 4.712571 & 14.44444 & 6.630207 & 10.62770 & 0.596758 \\
\hline Probability & 0.094772 & 0.000730 & 0.036330 & 0.004923 & 0.742020 \\
\hline Observations & 60 & 60 & 60 & 60 & 60 \\
\hline
\end{tabular}

\section{Source: Generated from Eview, 2020}

It was evident that oil and gas firms had made an increment in firm value to a maximum of 0.057895 with minimum value of 0.000120 . This shows that some of the companies have made low firm value over the last ten years hence, it is necessary for them to monitor their performance because the higher the firm value, the better the organization and it also signal to the shareholders that the company is doing better. In the same way, some of the companies are audited by Big 4 and few of them are not audited by the Big 4 as evident from the maximum of 1 signifying the 
International Journal of Social Science and Economic Research

ISSN: 2455-8834

Volume:06, Issue:02 "February 2021"

presence of Big 4 in the audit process and 0 signifying that some of the companies are not audited by Big 4 . The moderated board dynamics, board diversity and board proficiency have a minimum of 0.000000 because of the presence of non-big 4 in the audit process while their corresponding maximum value across the three variables are $13.00000,0.555556$ and 4.000000 .

Table 2: Correlation Result

\begin{tabular}{|c|c|c|c|c|c|}
\hline & FV & AQ & AQ_BM & AQ_BD & AQ_BP \\
\hline FV & 1.000000 & & & & \\
\hline AQ & -0.155962 & 1.000000 & & & \\
\hline AQ_BM & -0.234183 & 0.888052 & 1.000000 & & \\
\hline AQ_BD & 0.423717 & 0.447410 & 0.453437 & 1.000000 & \\
\hline AQ_BP & -0.266976 & 0.801218 & 0.872523 & 0.280058 & 1.000000 \\
\hline
\end{tabular}

\section{Source: Generated from Eview, 2020}

The above result depicts the relationship between audit quality, board dynamics variables and firm value. It was found that the variables are moderately related and there is no multicollinearity problem between the variables. Audit quality, moderated board magnitude and moderated board proficiency has negative relationship with firm value while moderated board diversity has positive relationship with firm value. Also, moderated board magnitude, moderated board diversity and moderated board proficiency has positive relationship with audit quality. 
International Journal of Social Science and Economic Research

ISSN: 2455-8834

Volume:06, Issue:02 "February 2021"

Table 3: Normality Test

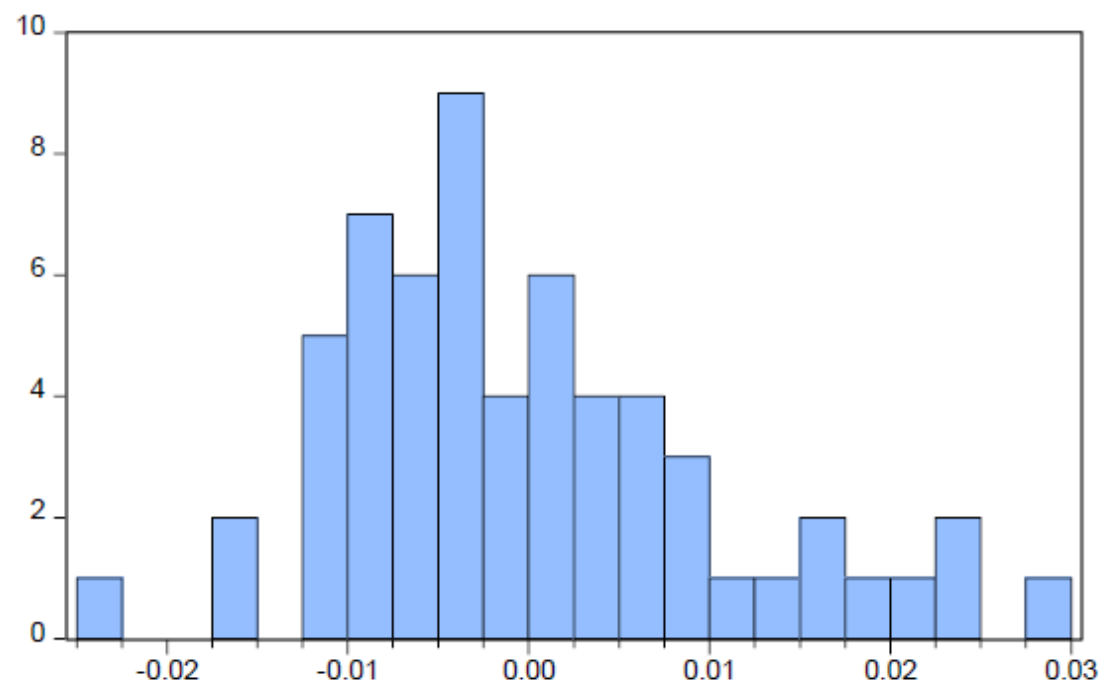

Series: Standardized Residuals Sample 20102019

Observations 60

Mean 2.83e-18

Median $\quad-0.002606$

Maximum $\quad 0.029178$

Minimum $\quad-0.022669$

Std. Dev. $\quad 0.010722$

Skewness $\quad 0.746206$

Kurtosis $\quad 3.331890$

Jarque-Bera $\quad 5.843614$

Probability $\quad 0.053836$

Source: Generated from Eview, 2020

The residual of the variable is tested to ascertain the normality of the variables and from the pvalue which is greater than $5 \%$ significance level, it signifies that the variables are normality distributed.

\section{Table 4: Hausman Test}

\section{Correlated Random Effects - Hausman Test}

Equation: Untitled

- Test period random effects

\begin{tabular}{lccc}
\hline \hline Test Summary & $\begin{array}{c}\text { Chi-Sq. } \\
\text { Statistic }\end{array}$ & Chi-Sq. d.f. & Prob. \\
\hline \hline Period random & 2.569346 & 4 & 0.6323 \\
\hline \hline
\end{tabular}

** WARNING: estimated period random effects variance is zero.

\section{Source: Generated from Eview, 2020}

Hausman result is used to guide the study on the appropriate model. From the p-value of the 


\section{International Journal of Social Science and Economic Research}

ISSN: 2455-8834

Volume:06, Issue:02 "February 2021"

result which is greater than $5 \%$ confidence level, it specifies that random model is appropriate in testing the stated hypotheses of the study.

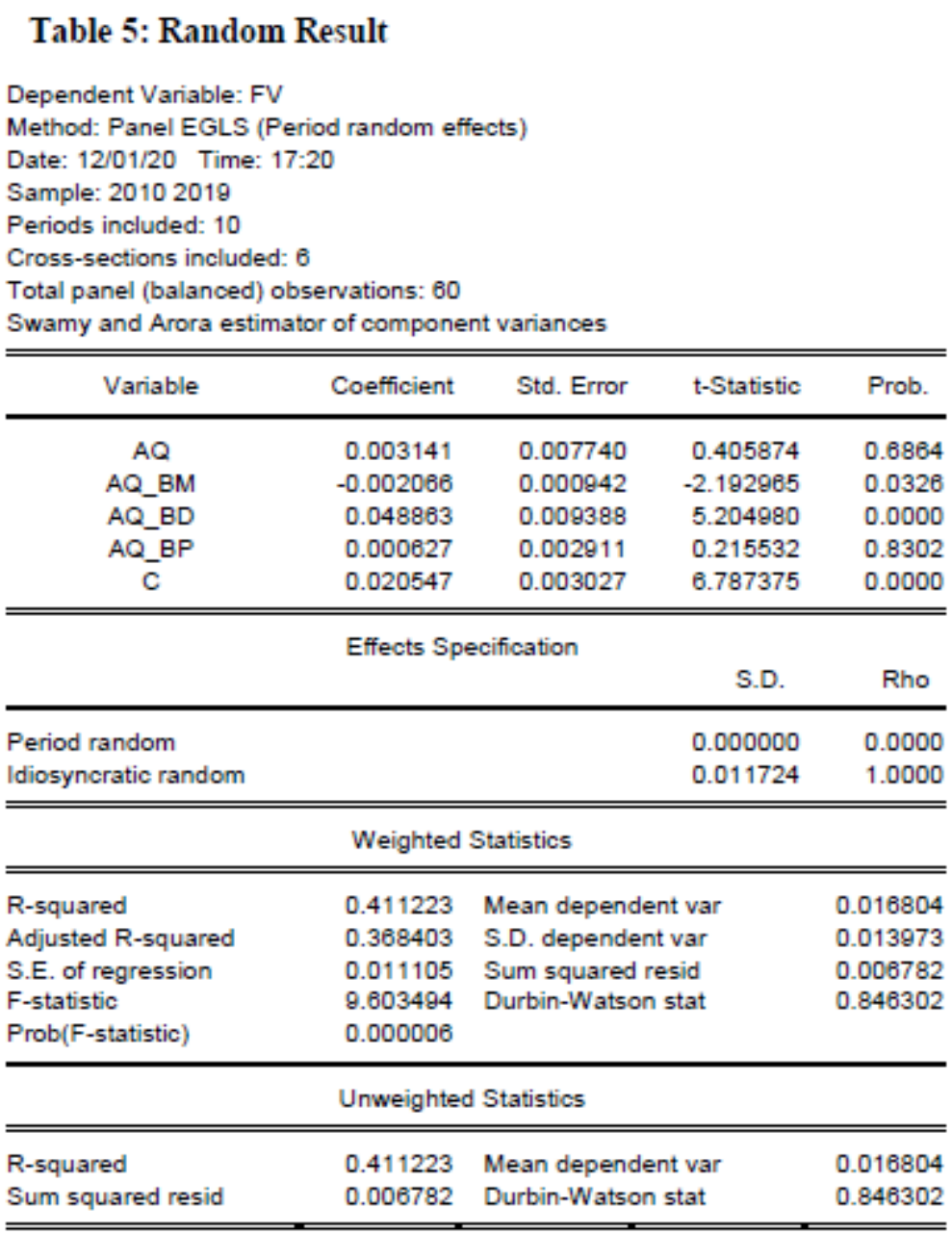

Source: Generated from Eview, 2020

The model of the study explained variation on firm value to the extent of approximately $41 \%$ while the remaining variation is explained by other board dynamics that were not captured by this model. Despite this, the model is fit with less than $5 \%$ f-statistics.

The result shows that audit quality has positive but insignificant effect on firm value while moderated board magnitude has negative and significant effect on firm value. This shows external auditors needs to be careful in monitoring the activities of the board. This finding fails to accept the stated null hypothesis hence, audit quality moderate the relationship between board magnitude and firm value of oil and gas companies in Nigeria. The finding is tantamount to the finding of Dincer and Dincer (2013); Kamangue and Ngugi (2013); Gurusamy (2017) but 


\section{International Journal of Social Science and Economic Research}

ISSN: $2455-8834$

Volume:06, Issue:02 "February 2021"

contrary to the finding of Suparno and Pitoyo (2016). The study negates the finding of Villanueva-Villar, Rivo-López and Lago-Penas (2016) that board magnitude has positive effect on firm value.

Moderated board diversity has positive and significant effect on firm value. This shows that when female directors are been monitored, they tend to carried out their duties with due professional skills in order to improve organizational firm value as it is indicated by the statistical evidence. Increase in one female director in the board will increase firm value by coefficient of 0.048863. this finding corroborates Pucheta-Martínez, Bel-Oms and Olcina-Sempere (2016), Baldavoo and Nomlala (2019) findings. However, the study found that moderated board proficiency has positive but insignificant effect on firm value which signifies that monitoring of board proficiency by external auditor has no yielded any significant effect in listed oil and gas companies over the last ten years. This study fails to reject the stated hypothesis that audit quality has no significant moderating effect on the relationship between board proficiency and firm value.

On the overall findings, audit quality plays a significant role in monitoring the daily activities of the management as detailed from the model of the study.

\section{CONCLUSIONS AND RECOMMENDATIONS}

The study investigates the moderating effect of audit quality on the relationship between board dynamics and firm value and from the finding, the study concludes that moderated board magnitude has negative and significant effect on firm value which signal reduction in the wealth of the shareholders. This shows that external auditors need to be careful in monitoring daily routine of board magnitude. Also, the study concludes audit quality plays a significant role in monitoring board diversity because it translates into increase in firm value positively however, moderated board proficiency has no significant effect on firm value. Based on the finding and conclusion of this study, it therefore means that audit quality gives credence to the financial reports of an organization therefore, oil and gas companies should engage the services of reputable audit firms that can monitor the activities of the board in order to improve their firm value. Also, women directors due to their different working and non-working experiences are expected to have different perspectives than men in some fields and some segments of the market. This will improve the company firm value. Therefore, those firms without female representation should endeavor to bring in female director(s) so as to enjoy such benefit in their organization.

\section{REFERENCES}




\section{International Journal of Social Science and Economic Research}

ISSN: $2455-8834$

Volume:06, Issue:02 "February 2021"

Adeyemi, S. B., \& Akuniyi, O. K. (2010). Stakeholders perception of independence of statutory auditors in Nigeria. Serbian Journal of management, 2, 247-267

Baldavoo, K., \& Nomlala, B. C. (2019). Audit Quality and Corporate Governance as Determinants of Banks’ Performance in Ghana. Acta Universitatis Danubius, 15 (7).

Blue Ribbon Committee (1999). Report and recommendations of the Blue Ribbon Committee on improving the effectiveness of corporate audit committees: NYSE and National Association of Securities Dealers.

Borlea, S. N., \&Achim, M. V. (2013). Theories of corporate governance. Economics Series, 23(1), 117-128.

Cahan, S. F., \& Sun, J. (2015). The effect of audit experience on audit fees and audit quality.Journal of Accounting, Auditing \& Finance, 30(1), pp. 78-100.

DeAngelo, L. E. (1981). Auditor size and audit quality. Journal of Accounting and Economics, 3 (3), $183-199$.

DeFond, M. J., Hann, R. N., \& Hu, X. (2005). Does the market value financial expertise on audit committees of boards of directors? Journal of Accounting Research, 43(2), 153-194.

Dincer, B., \& Dincer, C. (2013). Corporate governance and market value: Evidence from Turkish banks. International Journal of Academic Research in Business and Social Sciences, 3(1),241249.

Fama, E., \& Jensen, M. (1983). Agency problems and residual claims. The Journal of Law and Economics, 26(2), 327-349.

Fama, E.F. (1980). Agency problems and the theory of the firm. Journal of Political Economy, 88,

288- 307. http://dx.doi.org/10.1086/260866

Fama, E.F., \& Jensen, M.C. (1983). Separation of ownership and control. Journal of Law and Economics, 26, 301-325. http://dx.doi.org/10.1086/467037

Güleryüz, F. (2009). Value Based Management. Asomedy in March. Retrieved on February 15, 2015 from

http://www.aso.org.tt/kurumsal/media/kavnak/TUR/asomedva/mart2005/buvutec mart2005.html

Gurusamy, P. (2017). Board Characteristics, Audit Committee and Ownership Structure Influence on Firm Performance of Manufacturing Firms in India. International Journal of Business and 


\section{International Journal of Social Science and Economic Research}

ISSN: $2455-8834$

Volume:06, Issue:02 "February 2021"

Economics Research. 6(4), 73-87.

Hasnawati, S. (2005). Dampak set peluang investasi terhadap nilai perusahaan publik di bursa efek jakarta. Jaai vol. (9)2, 117 - 126.

Jensen, M. \& Meckling, W.H. (1976). Theory of the firm: managerial behavior, agency costs, and ownership structure. Journal of Financial Economics, 3, 305-360.

Jensen, M.C. (1993). The Modern Industrial Revolution, Exit, and the Failure of Internal Control System. Journal of Finance, 48: 831-880.

Kamangue, C. W., \& Ngugi, J. K. (2013). The influence of board attributes on firm value: A case study of the unit trusts in Kenya. European Journal of Management Sciences and Economics, 1(2), 58-69.

Kirchmaier, T., \& Grant, J. (2005). Corporate ownership structure and performance in Europe.European Management Review, 2(3): 231-245.

Knouse, S. B., \& Dansby, M. R. (1999). Percentage of workgroup diversity and workgroup effectiveness. The Journal of Psychology, 133: 486494.

Kumar, B. R. (2015). Determinants of Value Creation: An Empirical Examination from UAE Market. International Journal of Economics and Financial Issues, 5(1), 75-85.

Kyereboah-Coleman, A. (2008). Corporate governance and firm performance in Africa: A dynamic panel data analysis. Journal for Studies in Economics and Econometrics,32 (2), 1-24.

Makki, M. A. M., \& Lodhi, S. A. (2013). Impact of corporate governance on firm's performance.

Pakistan Journal of Social Sciences, 33 (2), 265-280.

Masdoor, K. A. (2011). Ethical theories of corporate governance. International Journal of Governance, 1(2).

Mautz, R., \& Sharaf, H (1961). The Philosophy of Auditing. American Accounting Association Monograph, 6.

Modigliani, F., \& Miller, M.H. (1958). The cost of capital, corporate on finance and the theory of investment. The American economicreview,48(3), pp.261-297.

Nguyen, T., Locke, S., \& Reddy, K. (2014). A dynamic estimation of governance structures and financial performance for Singaporean companies. Economic Modelling, 40(C), 1-11. 
International Journal of Social Science and Economic Research

ISSN: 2455-8834

Volume:06, Issue:02 "February 2021"

Nurul, K., Andrew, C. W., \& Gupta, R. (2014). Comparative Credit Risk in Islamic and Conventional Banks. Pacific-Basin Finance Journal, 34.

Okeahalam, C. C., \& Akinboade, O. A (2003). A review of corporate governance in Africa: Literature, Issues and Challenges. Paper prepared for the global corporate governance forum.

Panahi, B., Preece, C. N., Zakaria, W. N. W., \& Rogers, J., (2014). The correlation of EVA and MVA with stock price of companies in Tehran Stock Market, Interdisciplinary Journal of Contemporary Research in Business, 6(2), 291-309.

Porte, R. L., Florencio, L., \& Shleifer, A. (2002). Government ownership of banks. Journal of Finance, 57(1), 265-301.

Pucheta-Martínez, M. C., Bel-Oms, I., \& OlcinaSempere, G. (2016). Female institutional directors on boards and firm value of nonfinancial firms listed on the Madrid Stock Exchange.

Sasidharan, A., \& Varghese, G. (2019). Impact of Ownership Structure and Board Characteristics on Firm Value: Evidence from China and India. IFMR Graduate School of Business Wp19-008 Version No. 1

Shleifer, A., \& Vishny, R. W. (1997). A survey of corporate governance. The Journal of Finance, $\operatorname{LII}(2), 737-783$.

Suparno, S., \& Pitoyo, D. (2016). Determinant Factor of Firm's Value on Manufacturing Company in Indonesian Stock Exchange. Advances in Economics, Business and Management Research, $15,138-147$.

Switzer, L. N., \& Tang, M. (2009). The Impact of Corporate Governance on the Performance of U.S. Small-Cap Firms. International Journal of Business, 14(4).

Villanueva-Villar, M., Rivo-López, E., \& Lago-Penas, S. (2016). On the relationship between corporate governance and value creation in an economic crisis: Empirical evidence for the Spanish case. Business Research Quarterly, 19, 233-245.

Wanyama, W. D., \& Olweny, T. (2013). Effects of corporate governance on financial performance of listed insurance firms in Kenya. Public Policy and Administration Research, 3(4), 96- 120.

Watts, R. L., \& Zimmerman, J. E. (1983). Agency Problems, Auditing and the Theory of the Firm: Some Evidence, Journal of Law and Economics, 26, 613-633

Watts, R. L., \& Zimmerman, J. L. (1983). Agency problems, auditing and theory of the firm: Some 
International Journal of Social Science and Economic Research

ISSN: 2455-8834

Volume:06, Issue:02 "February 2021"

evidence. Journal of law and economics, xxvi, 613-633.

Yusoff, W. F. W., \& Alhaji, I. A. (2012). Corporate governance and firm performance of listed companies in Malaysia. Trends and Development in Management Studies, 1(1), 43-65.

Zhang, Y. (2017). Client importance and audit quality, office level evidence from the banking industry: a pitch. Accounting Research Journal, 30(2), pp. 147-152. 